\title{
Introduction
}

\section{An introduction to the review article by Jean-Claude Colliard entitled The influence of political parties on the Constitution}

French Politics (2009) 7, 31. doi:10.1057/fp.2009.3

The paper that follows is a revised version of a paper delivered to an Oxford conference, 'The Fifth Republic at Fifty: The Reciprocal Influence of Institutions on Parties \& of Parties on Institutions'. The organizers believe that these reciprocal relationships are central to the study of politics more generally, but are also particularly applicable to the understanding of the evolution of the Fifth Republic, whose constitution was predicated on the belief that stability could not come from an irremediably fractured party system, but had to be imposed on a recalcitrant Assembly by constitutional constraints enforced by a Constitutional Council and especially by an indirectly elected President, acting as arbiter, with the power to dissolve the Assembly and to decide whether to call referendums. No one in 1958 imagined that the French party system might evolve in a bipolar direction regularly producing parliamentary majorities, more often than not supporting a directly elected President (an option hardly considered then, for where was the popular majority to elect the President except through sordid partisan horse-trading that would have sapped his prestige and capacity for independent action to save the Assembly from itself?).

Professor Jean-Claude Colliard is a distinguished constitutional lawyer and political scientist, teaching in the Department of Political Science at Paris I, Sorbonne-Pantheon, with substantial political experience (in the Socialist party) and governmental too (as chef de cabinet to President Mitterrand, 1981-1988). His paper addresses both sides of the reciprocal relationship, but concentrates on the less discussed but crucial influence of parties (and political actors) on constitutional arrangements supposedly insulated from their machinations.

David Goldey

Emeritus Fellow in Politics, Lincoln College, Oxford University, OX1 3DR, UK E-mail: david.goldey@lincoln.ox.ac.uk 